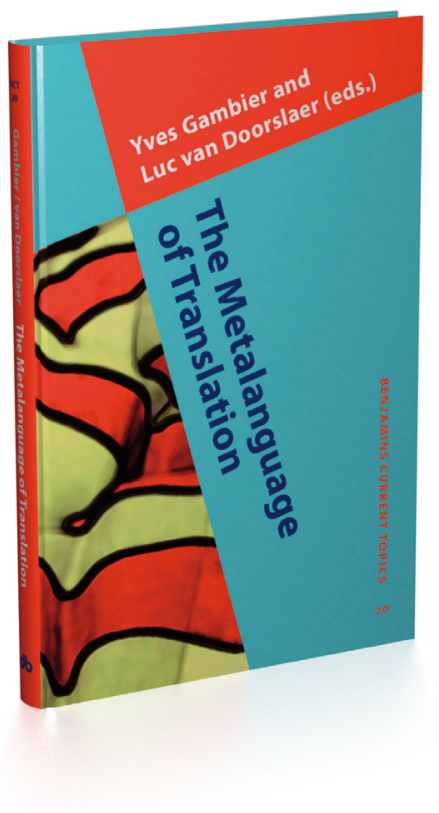

"The metalanguage that we inhabit as translation scholars is so natural to us that we often forget how much it guides our thoughts, delineates the blind spots in our thinking, determines our partners for intellectual debate, and defines the terms of that debate. This volume, which moves freely between epistemological reflection and practical recommendations, and which ranges from Aristotle to the terminology of software localization, is a very important contribution to a very important discussion." Dirk Delabastita, University of Namur, Belgium

"This volume clearly illustrates that the time has come to reflect on the scholarly discourse in Translation Studies as it has evolved over the last few decades. The essays bring together the relevant points of this discussion and critically question the language which has shaped the discipline of Translation Studies. A must for anyone interested in transdisciplinary work involving translation." Michaela Wolf, University of Graz, Austria

Translation \& Interpreting Studies

\title{
The Metalanguage of Translation
}

\section{Edited by Yves Gambier and Luc van Doorslaer}

University of Turku / Lessius University College, Antwerp and CETRA, University of Leuven

"Let the meta-discussion begin," James Holmes urged in 1972. Coming almost forty years later - years filled with fascinating and often unexpected developments in the interdiscipline of Translation Studies - this volume offers the reader a multiplicity of metaperspectives, while also moving the discussion forward. Indeed, the (re)production and (re)use of metalinguistic metaphors frame and partly determine our views on research, so such a discussion is vital as it is in any scholarly discipline. Among other questions, the eleven contributors draw the reader's attention to the often puzzling variations of usage and conceptualization in both the theory and the practice of translation. First published as a special issue of Target 19:2 (2007), the volume runs the gamut of metalinguistic topics, ranging from terminology, localization and epistemological questions, through the Chinese perspective, to the conceptual mapping of the online Translation Studies Bibliography.

[Benjamins Current Topics, 20] 2009. vi, $192 \mathrm{pp}$.

HB 9789027222503 EUR 85.0O

Table of contents

How about meta? An introduction

Yves Gambier and Luc van Doorslaer

Defining patterns in Translation Studies: Revisiting

two classics of German Translationswissenschaft

Gernot Hebenstreit

Risking conceptual maps: Mapping as a keywords-related tool underlying the online Translation Studies Bibliography Luc van Doorslaer

Polysemy and synonymy: Their management in Translation Studies dictionaries and in translator training. A case study Leona Van Vaerenbergh

The terminology of translation: Epistemological, conceptual and intercultural problems and their social consequences Josep Marco

Natural and directional equivalence

in theories of translation

Anthony Pym
A literary work - Translation and original:

A conceptual analysis within the philosophy of art and Translation Studies Leena Laiho

"What's in a name?": On metalinguistic confusion in Translation Studies Mary Snell-Hornby

In defence of fuzziness Nike K. Pokorn

The metalanguage of localization: Theory and practice Iwona Mazur

The metalanguage of translation:

A Chinese perspective

Jun Tang

Translation terminology and its offshoots Yves Gambier

\section{JOHN BENJAMINS PUBLISHING COMPANY www.benjamins.com}

